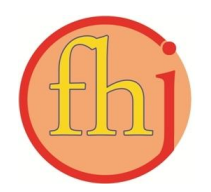

Faletehan Health Journal, 6 (1) (2019) 30-36

www. journal.Ippm-stikesfa.ac.id/ojs/index.php/FHJ

ISSN 2088-673X | e-ISSN 2597-8667

\title{
Hubungan Pengetahuan, Pendidikan dan Dukungan Keluarga dengan Pemberian ASI Eksklusif
}

\author{
Refi Lindawati ${ }^{*}$ \\ 1Prodi Diploma III Kebidanan, Sekolah Tinggi Ilmu Kesehatan Faletehan, Serang, Banten, Indonesia \\ *corresponden author : refilindawati@yahoo.co.id
}

\begin{abstract}
Abstrak
ASI merupakan sumber gizi yang sangat ideal dengan komposisi yang seimbang dan disesuaikan dengan kebutuhan pertumbuhan bayi. Berdasarkan data SDKI 2012, bayi yang menyusui eksklusif sampai 6 bulan yaitu sebesar 42 persen. Penyebab utama adalah rendahnya pengetahuan ibu dan kurangnya dukungan keluarga dalam pemberian ASI. Desa Peucangpari adalah salah satu desa di wilayah kerja Puskesmas Cigemblong Kabupaten Lebak Banten yang cakupan pemberian ASI eksklusif masih rendah, yaitu hanya sebesar 11,9\%. Tujuan penelitian ini untuk mengetahui hubungan pengetahuan, pendidikan dan dukungan keluarga dengan pemberian ASI eksklusif. Penelitian ini bersifat korelasi dengan pendekatan cross sectional. Populasi dalam penelitian ini adalah ibu yang memiliki bayi usia 6-24 bulan di Desa Peucangpari Kecamatan Cigemblong Lebak sebanyak 42 orang, sampel penelitian diambil dengan menggunakan teknik total populasi. Hasil penelitian menunjukkan ada hubungan antara pengetahuan, pendidikan, dan dukungan keluarga dengan pemberian ASI eksklusif di Desa Peucangpari Kecamatan Cigemblong Lebak Tahun 2018. Peneliti menyarankan perlu memberikan pendidikan kesehatan pada seluruh masyarakat, khususnya ibu yang memiliki bayi tentang manfaat ASI eksklusif, sehingga masyarakat atau ibu yang belum memberikan ASI eksklusif pada bayinya bisa bertambah pengetahuannya dan akan memberikan ASl eksklusif pada bayinya.
\end{abstract}

Kata kunci: Asi Ekslusif, Dukungan Keluarga, Pendidikan, Pengetahuan

\begin{abstract}
ASI is an ideal source of nutrition with a balanced composition and adapted to the baby's growth needs. Based on data from the 2012 IDHS, babies who exclusively breastfed up to 6 months were 42 percent. The main causesare low maternal knowledge and lack of family support in breastfeeding. Peucangpari Village is one of the villages in the working area of Cigemblong Health Center, Lebak, Banten, where the coverage of exclusive breastfeeding is still low, which is only $11.9 \%$. The purpose of this study was to determine the relationship between knowledge, education and family support with exclusive breastfeeding. This study is a correlation with a cross sectional approach. The population in this study were mothers who had babies aged 6-24 months in Peucangpari Village, Cigemblong Lebak as many as 42 people, the study sample was taken using a total population technique. The results showed that there was a relationship between knowledge, education, and family support with exclusive breastfeeding in Peucangpari Village, Cigemblong Lebak in 2018. Researchers suggested the need to provide health education to all communities, especially mothers who have babies about the benefits of exclusive breastfeeding, so that the community or mother those who have not given exclusive breastfeeding to their babies can increase their knowledge and will give exclusive breastfeeding to their babies. Keywords: Asi Exclusive, Education, Family Support, Knowledge
\end{abstract}


Faletehan Health Journal, 6 (1) (2019) 30-36

www. journal.Ippm-stikesfa.ac.id/ojs/index.php/FHJ

ISSN 2088-673X | 2597-8667

\section{Pendahuluan}

ASI eksklusif atau lebih tepat pemberian ASI secara eksklusif adalah bayi hanya diberikan air susu tanpa makanan tambahan lain dianjurkan sampai 6 bulan dan disusui sedini mungkin (Siswoyo, 2014). Pemberian ASI eksklusif sampai bayi umur 6 bulan dapat melindungi bayi dari berbagai penyakit penyebab kematian bayi. Selain menguntungkan bayi, pemberian ASI Eksklusif juga menguntungkan ibu, yaitu mengurangi perdarahan pasca persalinan, mengurangi kehilangan darah pada saat haid mempercepat pencapaian berat badan sebelum hamil, mengurangi risiko kanker payudara, dan kanker rahim. Meskipun menyusui dan ASI sangat bermanfaat, diperkirakan 85 persen ibu-ibu di dunia tidak memberikan ASI secara optimal. Hal ini tampak bahwa pemberian ASI eksklusif seperti yang direkomendasikan oleh WHO (2002) masih jarang dipraktikan oleh ibu-ibu di berbagai negara, karena berbagai faktor, seperti sosial, budaya, ekonomi, dan politik (Widodo, 2011).

Pemberian air susu ibu (ASI) eksklusif di dunia masih rendah. Berdasarkan data dari United Nations Children's Fund (UNICEF) pada tahun 2012 hanya $39 \%$ bayi di bawah usia 6 bulan yang mendapatkan ASI secara eksklusif di seluruh dunia, angka tersebut juga tidak mengalami kenaikan pada tahun 2015, yaitu hanya $40 \%$ keberhasilan pemberian ASI Eksklusif di seluruh dunia. Cina yang merupakan salah satu negara dengan jumlah populasi penduduk yang cukup besar di dunia hanya memiliki angka keberhasilan ASI eksklusif sebesar 28\%. Sedangkan negaranegara yang menduduki posisi 3 angka pemberian ASI eksklusif terendah dunia menurut data UNICEF antara lain Somalia, dan Afrika Selatan (WHO, 2015).

Pemberian ASI eksklusif di Indonesia juga masih kurang bahkan menurun. Berdasarkan perhitungan persentase ASI yang terbaru berdasarkan data Riskesdas yang terakhir tahun 2013, keberhasilan pemberian ASI eksklusif hanya sebesar 54,3\%. Pada tahun 2014 menurut data dari Survei Sosial Ekonomi Nasioanal (Susenas) persentase ASI menurun menjadi $33,6 \%$. Persentase pemberian ASI eksklusif secara nasional diperoleh angka tertinggi terdapat pada Provinsi Nusa Tenggara Barat (79,7\%), sedangkan persentase yang terendah terdapat pada Provinsi Maluku (25,2\%), sedangkan di Provinsi Banten cakupan ASI eksklusif sebesar 47,9\% (Riskesdas, 2013,).

Hasil Survei Demografi Kesehatan Indonesia (SDKI, 2012), menunjukkan sebanyak $8 \%$ bayi baru lahir mendapat ASI dalam 1 jam pertama setelah lahir dan $53 \%$ bayi mendapat ASI pada hari pertama. Proporsi anak yang diberi ASI pada hari pertama mencapai $51 \%$ dengan penolong bidan atau dokter kandungan sedangkan $67 \%$ anak mendapat ASI pada hari pertama tanpa penolong/ dukun. Hal ini menunjukkan bahwa ada pemberian tambahan selain ASI di bawah usia 6 bulan. Data SDKI tahun 2012 menunjukkan konsumsi pemberian MP ASI di bawah 6 bulan mencapai 35\% (SDKI, 2012).

UNICEF memperkirakan bahwa pemberian ASI eksklusif sampai usia 6 bulan dapat mencegah kematian 1,3 juta anak berusia di bawah 5 tahun. Suatu penelitian di Ghana yang diterbitkan dalam Jurnal Pediatrics menunjukkan 16\% kematian bayi dapat dicegah dengan pemberian ASI sejak pertama kelahirannya. Angka ini naik 22\% jika pemberian ASI dimulai dalam 1 jam pertama setelah kelahiran bayi (Prasetyono, 2009). Anjuran pemberian ASI eksklusif di Indonesia dipertegas dengan Peraturan Pemerintah Nomor 33 tahun 2012 tentang Pemberian ASI eksklusif. Peraturan ini menyatakan kewajiban ibu untuk menyusui bayinya secara eksklusif sejak lahir sampai berusia 6 bulan. Tapi nyatanya, realisasi dari peraturan pemerintah tersebut masih kurang. Menurut Survei Demografi dan Kesehatan Indonesia (SDKI) 2012, yaitu sebesar $42 \%$, sedangkan pemberian ASI 0-6 bulan menurut Pusat Data dan Informasi Pertanian (Pusdatin) 2015 sebesar 54,3\% dan berdasarkan data Dinas Kesehatan (Dinkes) Provinsi Banten, presentase cakupan ASI eksklusif 2016 sekitar 55,75\% (Profil Dinkes Provinsi Banten, 2017).

Hasil penelitian yang dilakukan oleh Mulyana menyatakan bahwa ada hubungan yang kuat antara pengetahuan ibu tentang ASI dengan pemberian ASI eksklusif pada bayi (Mulyana, 2008). Hubungan antara pengetahuan ibu tentang ASI terhadap pemberian ASI eksklusif menunjukan tingkat pengetahuan yang dimiliki seseorang mempengaruhi prakteknya sebagaimana teori yang dikemukakan oleh Green, bahwa pengetahuan seseorang merupakan faktor predisposisi untuk bertindak. Pemberian ASI eksklusif merupakan salah satu bentuk perilaku kesehatan masyarakat. Menurut Green dalam Notoatmodjo, perilaku dipengaruhi oleh tiga faktor utama yaitu; 1) Faktor 
predisposisi, seperti pengetahuan, individu, sikap, kepercayaan, tradisi, norma sosial, dan unsur-unsur lain yang terdapat dalam diri individu dan masyarakat, 2) Faktor pendukung, seperti tersedianya sarana pelayanan kesehatan dan kemudahan untuk mencapainya, 3) Faktor-faktor pendorong, seperti sikap dan perilaku petugas kesehatan (Notoatmodjo, 2003).

Banyak alasan yang menjadi faktor ibu tidak memberikan ASI ekslusif kepada bayinya, penyebab utama adalah kesadaran akan pentingnya ASI, rasa percaya diri ibu yang masih kurang, rendahnya pengetahuan ibu tentang manfaat ASI dan kurangnya dukungan keluarga dalam pemberian ASI (Rilyani 2012).Menurut Penelitian Rahmawati (2010) beberapa faktor yang cukup mempengaruhi pola pemberian ASI eksklusif adalah usia ibu, 64,5\% ibu usia $<20$ tahun tidak memberikan ASI eksklusif. Variabel lain yang juga menjadi faktor ibu tidak memberikan ASI eksklusif adalah pendidikan, $58,7 \%$ ibu berpendidkan rendah tidak memberikan ASI eksklusif. Menurut penelitian Kristianto dan Sulistyorini (2013) pengetahuan ibu juga mernpengaruhi pemberian ASI eksklusif, sebanyak 73,6\% ibu dengan pengetahuan kurang tidak memberikan ASI secara eksklusif. Hasil penelitian Roesli (2008) menyatakan bahwa dukungan keluarga merupakan faktor eksternal yang paling besar pengaruhnya terhadap keberhasilan ASI eksklusif $(72,8 \%)$.

Hasil observasi data di Puskesmas Cigemblong Lebak, didapatkan data Desa Peucangpari salah satu desa di Wilayah Kerja Puskesmas Cigemblong Lebak yang memiliki cakupan pemberian ASI eksklusif sangat rendah. Berdasarkan data Puskesmas Cigemblong tahun 2016 diketahui bahwa dari 42 bayi di Desa Peucangpari hanya terdapat 5 bayi yang mendapatkan ASI eksklusif atau hanya sebesar 11,9\%. Hal tersebut masih sangat jauh dari target yang ditetapkan pemerintah dalam Peraturan Pemerintah Nomor 33 tahun 2012 tentang Pemberian ASI eksklusif yang menargetkan $85 \%$ bayi mendapat ASI eksklusif sejak lahir sampai berusia 6 bulan (Puskesmas Cigemblong, 2016). Berdasarkan latar belakang tersebut, mengingat bahwa pemberian ASI eksklusif mempunyai manfaat yang sangat besar bagi tumbuh kembang bayi yang seharusnya menjadi salah satu role model bagi masyarakat, maka penulis tertarik untuk melakukan penelitian tentang hubungan pengetahuan, pendidikan dan dukungan keluarga dengan pemberian ASI eksklusif di Desa Peucangpari Kecamatan Cigemblong Lebak tahun 2018. Penelitian ini bertujuan untuk mengetahui hubungan pengetahuan, pendidikan dan dukungan keluarga dengan pemberian ASI Eksklusif di Desa Peucangpari Kecamatan Cigemblong Lebak.

\section{Metodo Penelitian}

Penelitian ini menggunakan desain penelitian korelasional dengan pendekatan studi cross sectional. Penelitian dilaksanakan di Desa Peucangpari Kecamatan Cigemblong Kabupaten Lebak. Penelitian dilaksanakan pada bulan Februari-Mei 2018. Populasi dalam penelitian ini adalah seluruh ibu yang memiliki bayi usia 6-24 bulan di Desa Peucangpari Kecamatan Cigemblong. Berdasarkan data dari Puskesmas Cigemblong, di Desa Peucangpari terdapat 42 ibu yang memiliki bayi usia 6-24 bulan. Dikarenakan jumlah populasi kurang dari 100, maka teknik pengambilan sampel yang digunakan adalah total populasi, yaitu dengan mengambil semua anggota populasi menjadi subyek penelitian. Jadi besar sampel dalam penelitian ini adalah 42 responden. Pengumpulan data yang digunakan dalam penelitian ini yaitu menggunakan instrumen berupa kuesioner. Kuesioner tingkat pengetahuan tentang ASI Eksklusif terdiri dari 10 pertanyaan dengan pilihan jawaban multiple choice, dan kuesioner dukungan keluarga terdiri dari 10 pernyataan dengan pilihan jawaban ada dan tidak. Data diolah menggunakan analisis univariat untuk menggambarkan distribusi frekuensi variabel penelitian dan analisis bivariat menggunakan pendekatan uji chi-square untuk mengetahui hubungan antara variabel bebas dan variabel terikat penelitian.

\section{Hasil dan Pembahasan}

Berdasarkan tabel 1. menunjukkan bahwa pemberian ASI yang terbanyak adalah proporsi pemberian ASI tidak ekslusif yaitu 69,0 \%, proporsi pengetahuan kurang sebanyak $59,5 \%$, proporsi pendidikan rendah sebanyak $52,4 \%$, proporsi tidak ada dukungan keluarga sebanyak $64,3 \%$.

Pemberian ASI eksklusif adalah bayi hanya diberi ASI saja selama 6 bulan, tanpa tambahan cairan lain seperti susu formula, jeruk, madu, air, teh, dan air putih, serta tanpa tambahan makanan padat seperti pisang, bubur susu, biscuit, bubur 
Faletehan Health Journal, 6 (1) (2019) 30-36 www. journal.Ippm-stikesfa.ac.id/ojs/index.php/FHJ ISSN 2088-673X | 2597-8667

nasi, dan nasi tim (Kristiyanasari, 2011). Hasil penelitian menggambarkan bahwa sebagian besar ibu di Desa Peucangpari Kecamatan Cigemblong Kabupaten Lebak tidak memberikan ASI eksklusif pada bayinya $(66,1 \%)$. Hal tersebut sebenarnya patut disayangkan, mengingat ASI adalah makanan alami bayi yang memiliki keseimbangan zat-zat gizi yang terbaik yang tidak terdapat pada makanan bayi lainnya. Dan dengan memberikan ASI ibu juga bisa menghemat pengeluaran untuk membeli susu formula yang sebenarnya tidak lebih baik ketimbang ASI (Hubertin 2008).

Hasil penelitian ini sesuai dengan hasil penelitian Wargiana (2013) yang juga mendapatkan hasil bahwa pola pemberian ASI di Wilayah Kerja Puskesmas Rowotengah Kabupaten Jember masih kurang baik, yaitu sebanyak 78,7\% ibu tidak memberikan ASI eksklusif. Banyak faktor yang bisa mempengaruhi ibu mengapa tidak memberikan ASI secara eksklusif pada bayinya, berdasarkan hasil wawancara dengan beberapa responden peneliti mendapat gambaran bahwa salah satu faktor utama yang menyebabkan ibu tidak memberikan ASI eksklusif adalah dikarenakan kesibukan ibu dalam bekerja.

Banyak diantara ibu yang tidak memberikan ASI eksklusif menyatakan berhenti menyusui karena alasan sibuk bekerja dan bayinya tidak bisa dibawa ke tempat kerja. Alasan tersebut sekilas dapat diterima untuk orang yang tidak mempunyai pengetahuan tentang cara-cara memberikan ASI eksklusif selain harus menyusui secara langsung pada bayinya. Padahal ASI selain diberikan secara langsung dengan cara menyusui, juga dapat diberikan dengan menggunakan sendok dengan cara disuapkan sedikit-demi sedikit, yaitu pertama ASI diperah kemudian disimpan dalam tempat khusus yang bisa menjaga kualitas ASI dan kesterilannya untuk diberikan pada saat bayi lapar. Dengan cara tersebut tidak harus ibunya sendiri yang memberikan ASI tersebut, bisa dilakukan siapa saja yang bertugas mengasuh bayi tersebut. Berdasarkan hal tersebut, peneliti menyarankan kepada ibu-ibu yang bekerja untuk memiliki sarana-prasarana pemberian ASI eksklusif seperti pompa ASI (breast pump), botol khusus penyimpan ASI dan cool bag. Dengan memiliki sarana prasarana pemberian ASI tersebut maka ibu bisa terus dapat memberikan ASI eksklusif meskipun sibuk bekerja. (Insani 2011)

Tabel 1: Pemberian ASI ekslusif berdasarkan pengetahuan, pendidikan dan dukungan keluarga $(\mathrm{N}=42)$

\begin{tabular}{lcc}
\hline \multicolumn{1}{c}{ Variabel } & n & $\mathbf{( \% )}$ \\
\hline Pemberian ASI Ekslusif & & \\
Tidak Ekslusif & 29 & 69,0 \\
Ekslusif & 13 & 13,0 \\
\hline Pengetahuan & & \\
$\quad$ Kurang & 25 & 59,5 \\
$\quad$ Baik & 17 & 40,5 \\
\hline Pendidikan & & \\
$\quad$ Rendah & 22 & 52,4 \\
$\quad$ Tinggi & 20 & 47,6 \\
\hline Dukungan Keluarga & & \\
$\quad$ Tidak ada & 27 & 64,3 \\
$\quad$ Ada & 15 & 35,7 \\
\hline
\end{tabular}

Tabel 2: Hubungan pengetahuan, pendidikan, dan dukungan keluarga dengan pemberian ASI eksklusif (N=42)

\begin{tabular}{|c|c|c|c|c|c|}
\hline \multirow[t]{2}{*}{ Variabel } & \multicolumn{2}{|c|}{ Pemberian ASI Eksklusif } & \multirow[t]{2}{*}{ Total } & \multirow{2}{*}{$\begin{array}{c}P . \\
\text { Value }\end{array}$} & \multirow{2}{*}{$\begin{array}{c}\text { OR } \\
(\mathrm{CI}: 95 \%)\end{array}$} \\
\hline & Tidak Eksklusif & Eksklusif & & & \\
\hline \multicolumn{6}{|l|}{ Pengetahuan } \\
\hline kurang & $21(84,0 \%)$ & $4(16,0 \%)$ & $25(100 \%)$ & 0,028 & 5,906 \\
\hline baik & $8(47,1 \%)$ & $9(52,9 \%)$ & $17(100 \%)$ & & \\
\hline \multicolumn{6}{|l|}{ Pendidikan } \\
\hline rendah & $19(86,4 \%)$ & $3(13,6 \%)$ & $22(100 \%)$ & 0,027 & 6,333 \\
\hline Tinggi & $10(50,0 \%)$ & $20(50,0 \%)$ & $20(100 \%)$ & & \\
\hline \multicolumn{6}{|c|}{ Dukungan Keluarga } \\
\hline Kurang & $23(85,2 \%)$ & $4(14,8 \%)$ & $27(100 \%)$ & 0,005 & 8,625 \\
\hline Baik & $6(40,0 \%)$ & $9(60,0 \%)$ & $15(100 \%)$ & & \\
\hline
\end{tabular}


Berdasarkan tabel 2. diketahui bahwa variabel pengetahuan, pendidikan dan dukungan keluarga berhubungan secara signifikan dengan pemberian ASI eksklusif.

\section{Pengetahuan dengan pemberian ASI Ekslusif}

Dari hasil analisis pada tabel 2 menunjukkan terdapat hubungan antara pengetahuan dengan pemberian ASI eksklusif ( $\mathrm{p}$ value : 0,028). Hasil penelitian menunjukkan bahwa proporsi pemberian ASI eksklusif lebih banyak terdapat pada ibu yang memiliki pengetahuan baik dibandingkan pada ibu yang pengetahuannya kurang baik. Responden yang tidak memberikan ASI Eksklusif tersebut memberikan makanan lain antara lain madu, susu formula, bubur, air, dan pisang pada umur bayi kurang 6 bulan. Responden menyatakan bahwa ASI tidak cukup buat bayi sehingga harus diberikan makanan tambahan. Makanan tambahan ini dipercaya dapat membantu memenuhi kebutuhan makanan dan minuman bayi. Tingginya persentase yang tidak memberikan ASI Eksklusif disebabkan responden memang benarbenar tidak tahu arti pentingnya ASI Eksklusif bagi kesehatan bayi sehingga tidak termotivasi untuk memberikan ASI Eksklusif kepada bayinya.

Hal tersebut sesuai dengan teori yang dikemukakan oleh Notoatmodjo (2003) yang menyatakan bahwa pengetahuan merupakan domain yang sangat penting akan terbentuknya tindakan atau perilaku seseorang. Pengetahuan seseorang terhadap kesehatan merupakan salah satu faktor predisposisi yang mempengaruhi perilaku seseorang, jadi jika selama kehamilan tidak mendapatkan informasi atau penyuluhan mengenai ASI eksklusif maka akan berpengaruh terhadap perilaku ibu tersebut dalam pemberian ASI pada bayinya ( Suhartono 2012).

Hasil penelitian ini juga didukung oleh hasil penelitian Aulita (2011) yang memperoleh hasil ada hubungan antara pengetahuan ibu dengan pemberian ASI eksklusif pada bayi, dimana semakin baik pemahaman ibu tentang manfaat pemberian ASI eksklusif, maka ibu akan semakin termotivasi untuk memberikan ASI eksklusif kepada bayinya. Pengetahuan yang rendah tentang manfaat dan tujuan pemberian ASI eksklusif bisa menjadi penyebab gagalnya pemberian ASI eksklusif pada bayi. Kurangnya pengetahuan ibu bisa disebabkan pada saat pemeriksaan kehamilan (Ante Natal Care), ibu tidak memperoleh penyuluhan intensif tentang ASI eksklusif, kandungan dan manfaat ASI, teknik menyusui, dan kerugian jika tidak memberikan ASI eksklusif (Purwanti, 2008).

\section{Pendidikan dengan Pemberian ASI Eksklusif}

Dari hasil analisis hubungan antara pendidikan dengan pemberian ASI Eksklusif dengan menggunakan uji chi square didapat $\mathrm{p}$ value : 0,027 ( $\mathrm{p}$ value $<0,05$ ), hal tersebut bahwa secara statistik terdapat hubungan yang bermakna antara pendidikan dengan pemberian ASI eksklusif pada di Desa Peucangpari Kecamatan Cigemblong Kabupaten Lebak tahun 2018. Hasil penelitian menunjukkan bahwa proporsi pemberian ASI eksklusif lebih banyak terdapat pada ibu yang berpendidikan tinggi yaitu dengan latar belakang pendidikan yang lulus dari SLTA atau PT. Hal tersebut sesuai dengan teori yang menyatakan bahwa semakin tinggi tingkat pendidikan seseorang, maka semakin mudah menerima informasi sehingga akan semakin banyak pula pengetahuan yang dimiliki. Pendidikan yang cukup akan membuat seorang ibu semakin mudah menerima informasi mengenai manfaat ASI Eksklusif dari berbagai sumber sehingga pengetahuannya akan semakin bertambah ( Nursalam 2008 ).

Pendidikan akan mendorong seseorang untuk mengetahui sesuatu hal, seseorang yang mempunyai pendidikan tinggi lebih cendrung mengetahui manfaat ASI dibandingkan dengan yang berpendidikan rendah, hal tersebut disebabkan dengan pendidikan seseorang dapat lebih mengetahui sesuatu hal, tingkat pendidikan yang rendah akan susah mencerna pesan atau informasi yang disampaikan, (Notoatmodjo, 2003). Hasil penelitian ini sesuai dengan penelitian Soeparmanto (2004) yang menyebutkan bahwa ibu yang mempunyai pendidikan lebih tinggi memiliki kemungkinan menyusui ASI eksklusif 6 kali lebih besar dibandingkan ibu yang berpendidikan lebih rendah. Tingkat pendidikan merupakan salah satu aspek sosial yang dapat mempenggaruhi tingkah laku manusia. Pendidikan akan mempengaruhi seseorang dalam melakukan respon terhadap sesuatu yang datang dari luar. Orang yang mempunyai pendidikan lebih tinggi akan memberikan respon yang lebih rasional dibandingkan mereka mereka yang tidak berpendidikaan, karena mereka yang 
Faletehan Health Journal, 6 (1) (2019) 30-36

www. journal.Ippm-stikesfa.ac.id/ojs/index.php/FHJ

ISSN 2088-673X | 2597-8667

berpendidikan tinggi mampu menghadapi tantangan dengan rasional ( Soeparmanto, 2004 ).

\section{Dukungan keluarga dengan Pemberian ASI Ekslusif}

Hasil analisis hubungan antara dukungan keluarga dengan pemberian ASI eksklusif dengan menggunakan uji chi square didapat $\mathrm{p}$ value : 0,005 ( $\mathrm{p}$ value $<0,05$ ), yang berarti bahwa secara statistik terdapat hubungan yang bermakna antara dukungan keluarga dengan pemberian ASI eksklusif di Desa Peucangpari Kecamatan Cigemblong Kabupaten Lebak tahun 2018. Hasil penelitian menunjukkan bahwa proporsi pemberian ASI eksklusif lebih banyak terdapat pada ibu yang memiliki dukungan keluarga dibandingkan pada ibu yang tidak memiliki dukungan keluarga. Dukungan keluarga merupakan salah satu jenis dari dukungan sosial. Dukungan sosial pada umumnya menggambarkan mengenai peranan atau pengaruh yang dapat ditimbulkan oleh orang lain yang berarti seperti anggota keluarga, teman, saudara, dan rekan kerja. Dukungan sosial adalah pemberian bantuan seperti materi, emosi, dan informasi yang berpengaruh terhadap kesejahteraan manusia. Dukungan sosial juga dimaksudkan sebagai keberadaan dan kesediaan orang-orang yang berarti, yang dapat dipercaya untuk membantu, mendorong, menerima, dan menjaga individu. Sehingga dapat dikatakan bahwa dukungan Sosial adalah bentuk pertolongan yang dapat berupa materi, emosi, dan informasi yang diberikan oleh orang-orang yang memiliki arti seperti keluarga, sahabat, teman, saudara, rekan kerja ataupun atasan atau orang yang dicintai oleh individu yang bersangkutan. Bantuan atau pertolongan ini diberikan dengan tujuan individu yang mengalami masalah merasa diperhatikan, mendapat dukungan, dihargai dan dicintai.( Rasyka 2012).

Hal tersebut sesuai dengan teori yang menyatakan bahwa dukungan keluarga membuat seseorang memiliki kepercayaan diri dalam membuat keputusan. Kepercayaan ini akan menumbuhkan rasa aman, rasa percaya diri, harga diri, dan keberanian sehingga dukungan emosi yang diberikan keluarga merupakan salah satu pendorong seseorang untuk membuat suatu keputusan, dalam hal ini adalah keputusan ibu dalam pemberian ASI eksklusif (Friedman. 2010). Suami dan keluarga dapat berperan aktif dalam pemberian ASI dengan cara memberikan dukungan emosional atau praktis lainnya. Keberhasilan ibu tidak lepas dari peran serta keluarga. Dimana disebutkan bahwa semakin besar dukungan yang didapatkan ibu untuk terus menyusui bayinya secara Eksklusif, maka semakin besar pula kemampuan ibu untuk terus bertahan menyusui bayinya (Sohimah, 2013).

Hasil penelitian ini sejalan dengan hasil penelitian Roesli (2008) yang menyebutkan bahwa ibu yang memiliki dukungan keluarga lebih baik memiliki peluang menyusui secara ASI eksklusif 17 kali lebih besar dibandingkan ibu yang kurang memiliki dukungan keluarga. Dukungan keluarga merupakan faktor eksternal yang paling besar pengaruhnya terhadap keberhasilan ASI Eksklusif (72,8\%) ( Roesli 2008 ).

\section{Simpulan}

Berdasarkan hasil penelitian dapat disimpulkan bahwa sebanyak $69 \%$ responden tidak memberikan ASI eksklusif. Variabel pengetahuan, pendidikan dan dukungan keluarga berhubungan secara signifikan dengan pemberian ASI eksklusif.

\section{Referensi}

Aulita (2011). Faktor-Faktor Yang Mempengaruhi Pola Pemberian ASI Eksklusif. Jurnal Maternitas

Biro Pusat Statistik ( 2012 ). Survey Demografi dan Kesehatan Indonesia ( SDKI ) 2012. BPSBKKBN Depkes RI.

Friedman. (2010). Keperawatan Keluarga Teori dan Praktek. Edisi 5. Jakarta : EGC

Hubertin. (2008). Konsep Penerapan ASI Eksklusif, Malang : EGC

Insani. (2011). Keajaiban ASI makanan terbaik untuk kesehatan, kecerdasan, dan kelincahan si kecil, Yogyakarta: Andi

Kristiyanasari, Weni. (2011). Asi, menyusui \& sadari, Yogyakarta: Nuha medika.

Kristiyanto dan Sulistyorini (2013). Faktor-Faktor Yang Mempengaruhi Pola Pemberian ASI Eksklusif.

Mulyana. (2008). Hubungan Karakteristik dengan Pemberian ASI Eksklusif. Skripsi USU

Notoatmodjo, S.. (2003). Pendidikan dan Perilaku Kesehatan dan Ilmu Perilaku Kesehatan. Edisi 1, Jakarta: Rineka Cipta

(2010). Metode penelitian kesehatan, Edisi Revisi, Jakarta Rineka Cipta 
Faletehan Health Journal, 6 (1) (2019) 30-36

www. journal.Ippm-stikesfa.ac.id/ojs/index.php/FHJ

ISSN 2088-673X | 2597-8667

(2010). Metodologi Penelitian Kesehatan.

Jakarta: Rineka cipta

Nursalam. (2008). Pendidikan dalam Keperawatan. Jakarta: Penerbit Salemba Medika

Peraturan Pemerintah Republik Indonesia Nomor 33 Tahun 2012 Tentang Pemberian Air Susu Ibu Eksklusif

Purwanti (2008). Faktor-Faktor Yang Mempengaruhi Pola Pemberian ASI Eksklusif. Jurnal Kesehatan

Profil Dinas Kesehatan ( 2017 ). Tekan Angka Gizi Buruk, Banten Dorong Cakupan ASI Eksklusif. Provinsi Banten

Puskesmas Cigemblong ( 2017 ).Profil Puskesmas Cigemblong.Provinsi Banten

Rahmawati. (2010). Faktor-Faktor Yang Mempengaruhi Pola Pemberian ASI Eksklusif. Jurnal Kesehatan

Riskesdas. (2013). Riset Kesehatan Dasar. Jakarta: Kemenkes RI.

Roesli, U, (2008). Mengenal ASI eksklusif. Jakarta: Trubus Agriwidya.

Rasyika dkk (2012). Peran Keluarga dalam Pemberian ASI Ekslusrif di Kabupaten Jeneponto. Jurnal FKM UNHAS Makassar.
Rilyani dkk, (2012) Hubungan tingkat pendidikan, pengetahuan, sikap ibu dan dukungan keluarga terhadap pemberian ASI Ekslusif di Puskesmas Kedaton Bandar Lampung. Jurnal Dunia Kesmas Vol 1.

Siswoyo, D, (2014). Tujuan dan manfaat pemberian ASI eksklusif Akses tanggal 4 Juni 2016. http://hamizanupdate.blogspot.com.

Sohimah dkk (2013).Pengaruh Dukungan Keluarga dan Dukungan Tenaga Kesehatan terhadap Pemberian ASI Ekslusif. Prosiding STIKes Al-Irsyad Cilacap.

Suparmanto (2004). Karakteristik Dalam Pemberian ASI Eksklusif. Jakarta

Suhartono, Suparlan. (2008). Filsafat Ilmu Pengetahuan, Jogjakarta: Ar-Ruzz Media.

Wargiana dkk (2013). Hubungan Pemberian MPASI Dini dengan status gizi bayi umur 0-6 bulan di Wilayah Kerja Puskesmas Rowotengah Kabupaten Jember. Jurnal Pustaka Kesehatan, I ( no.1 )

Widodo,. K (2011). Asi Menyusui \& Sadari. Yogkarta: Muha Medika.

WHO. (2015). Global Strategy for Infant and Young Child Feeding. WHO: Geneva 